\title{
Mapping of slopes for the operation of agricultural harvesters in Bandeirantes Municipality (PR)
}

\section{Mapeamento da declividade operacional de colhedoras agrícolas para o Município de Bandeirantes (PR)}

\author{
Gustavo Rodrigues Gimenes ${ }^{1}$; Rone Batista de Oliveira ${ }^{2}$; Alessandra Fagioli da \\ Silva $^{2 *}$; Luiz Carlos Reis ${ }^{2}$; Teresinha Esteves da Silveira Reis ${ }^{2}$
}

\begin{abstract}
The slope of terrain represents a risk factor for mechanized harvesting, leading to impediments or restrictions on agricultural operations, or even to machines toppling over in the field. Recently, the Digital Terrain Model (DTM) has become widely adopted as one of the most viable techniques for obtaining slope and elevation. Therefore, this study aims to assess methods of acquiring DTMs to calculate the slope, and to determine the areas that are suitable and unsuitable for the operation of harvesters in the municipality of Bandeirantes (PR). Four methods were selected to produce DTMs for the construction of slope zoning maps applicable for harvester operations. The image sources included SRTM, ASTER GDEM, digitizing contour lines and kriging of spatial point data. After generating DTMs by the four different methods, the area suitable for the operation of harvesters was obtained based on the limits of operational slopes for harvesters in the literature. The high-resolution images, such as those obtained by scanning the contour lines and ASTER GDEM gave the best representation of the ground surface. Regardless of the method used to obtain the operational slopes, the municipality has a large area that is suitable for mechanized harvesting.
\end{abstract}

Key words: Terrain slope. Risk factor. Mechanized harvester.

\section{Resumo}

A declividade do terreno corresponde a um fator de risco para a colheita mecanizada, levando a restrições e impedimento das operações agrícolas ou até mesmo ao tombamento de máquinas no campo. O modelo numérico do terreno se difundiu nos últimos anos como uma das técnicas mais viáveis para obtenção da declividade e altimetria. Portanto, este trabalho teve como objetivo analisar metodologias de aquisição do modelo numérico do terreno para calcular a declividade e determinar as áreas aptas e inaptas para operacionalidade de colhedoras agrícolas no município de Bandeirantes (PR). Adotaram-se quatro métodos de obtenção do modelo numérico do terreno para a elaboração de mapas de zoneamento da declividade operacional de colhedoras agrícolas. Foram utilizadas imagens da missão SRTM, Aster Gdem, da digitalização das curvas de nível e interpolação por krigagem. Após a geração dos modelos numérico do terreno pelos diferentes métodos, obteve-se a declividade operacional da área com base na literatura. As imagens com alta resolução como as obtidas pela digitalização das curvas de nível e Aster Gdem forneceram uma representação mais adequada da superfície do terreno. O município possui uma grande área apta à colheita mecanizada, independentemente do método utilizado para a obtenção da declividade operacional.

Palavras-chave: Declividade do terreno. Fator de risco. Colheita mecanizada.

\footnotetext{
${ }^{1}$ M.e em Agronomia, Universidade Estadual do Norte do Paraná, UENP, Campus Luiz Meneghel, Bandeirantes, PR, Brasil. E-mail: gustavo.r.o@terra.com.br

2 Profs. Drs., UENP, Campus Luiz Meneghel, Bandeirantes, PR, Brasil. E-mail: rone@uenp.edu.br; alefagioli@hotmail.com; lcreis@uenp.edu.br; tsreis@uenp.edu.br

* Author for correspondence
} 


\section{Introduction}

Mechanical harvesting of sugarcane and grain crops, without proper knowledge of the terrain slope, coupled with the differences in soil types (sandy and clayey) and management strategies (direct and conventional planting systems), presents significant difficulties in the operation of machines that are designed to operate under more ideal conditions, such as a flat terrain and soil that is more resistant to erosion.

Topography influences soil characteristics, water flow patterns, transport of sediments and contaminants, hydrological behavior, irrigation methods, and therefore affects the yield of crops, quality of soil and water, and mechanized operations (KARKEE et al., 2008).

Slope is an important factor for mechanized harvesting, as the harvester machines are designed for land with the least possible slope (ORTEGA et al., 2009). In order to safely use harvesters, one can use both the operator's expertise in maintaining the harvesters within their stability limits, and the zoning of areas where agricultural operations can be performed. These act as a set of tools to assist decision-making in order to maximize income and prevention of accidents in the operation of machines in the field (OLIVEIRA et al., 2006).

The use of tools, such as DTM (SMITH et al., 2006; CHAGAS et al., 2010) and geostatistics (CAMPOS et al., 2009) are becoming increasingly common in agricultural sciences, providing a spatial and integrated view of environmental attributes, and replacing the subjectivity associated with conventional mapping methods for more objective and quantitative mapping methods. The DTM is a useful tool in soil mapping and its distribution in the landscape, which stands out in research on spatial and temporal variability, rendering it more accurate, without dispensing entirely with field support (SOUSA JÚNIOR; DEMATTÊ, 2008).

The images of the Shuttle Radar Topography Mission (SRTM), whose space mission was carried out in 2000, allowed generating the digital terrain model of virtually the entire globe ( $80 \%)$, at a level of unprecedented detail (JPL, 2012). The DTM derived from the SRTM are available for free to all of South America in the spatial resolution of $90 \mathrm{x}$ 90 meters.

Among the new generation of medium resolution satellites, the Terra satellite, which has the Advanced Space Borne Thermal Emission and Reflection Radiometer (ASTER) sensor on board, stands out. Since 2011, it has enabled the development of a DTM derived from stereoscopic pairs of ASTER satellite images produced by the VNIR sensor (data in the near infrared range) in the spatial resolution of $30 \times 30$ meters (ASTER, 2012).

Data from a DTM are represented by $\mathrm{x}, \mathrm{y}$ and $\mathrm{z}$ coordinates, where $\mathrm{z}$ is a function of $\mathrm{x}$ and $\mathrm{y}$. These data are usually sampled according to an irregular distribution in the $\mathrm{x}$ and $\mathrm{y}$ axes, or along lines with the same value of $z$, known as contours (VIVIANI; MANZATO, 2005). While it is not necessary to collect points with regular spacing to build a DTM, it is essential to have samples with the following pattern: have the most points sampled where there is the greatest variation of the phenomenon to be modeled, as well as points from over the entire region to be modeled (BARBOSA et al., 2012). As these samples constitute numerical data, one of most frequently applied methods of interpolation is ordinary kriging, which consists of linear regression techniques aimed at minimizing the variance of estimation from a model of covariance defined in advance (DEUTSCH; JOURNEL, 1998).

As an alternative to traditional methods, the use of these new methods of obtaining DTMs and slopes, such as using radar and satellites images, has spread in recent years, and can represent and identify the characteristics of terrain surfaces reliably, quickly and accurately. Therefore, this study aims to analyze methods of acquiring DTMs for the purpose of calculating the slope, and determine the suitable and unsuitable areas for operating harvesters. 


\section{Materials and Methods}

The research encompassed the entire municipality of Bandeirantes, PR, located in the rectangle bounded by UTM coordinates (Universal Transverse Mercator) 553,500 $\mathrm{m}$ to $581,100 \mathrm{~m}$ (W) and 7,453,000 $\mathrm{m}$ to 7,425,660 $\mathrm{m}(\mathrm{S}), 22$ South, datum SIRGAS 2000 (Figure 1). The municipality extends over an area of approximately $44,489.0$ ha, with an average altitude of 420 meters (IBGE, 2012). The predominant types of soils in the municipality are Red Yellow Latosol (LV - Latossolo Vermelho) and Red Acrisol (PV - Argissolo Vermelho) (MAACK, 1968; EMBRAPA, 2013). The area is kept in pasture and tillage, especially the crops of sugarcane, soybeans, corn, wheat, alfalfa, cotton, thin grape and coffee (REIS et al., 2009).

Figure 1. Location map of the Bandeirantes-PR municipality.

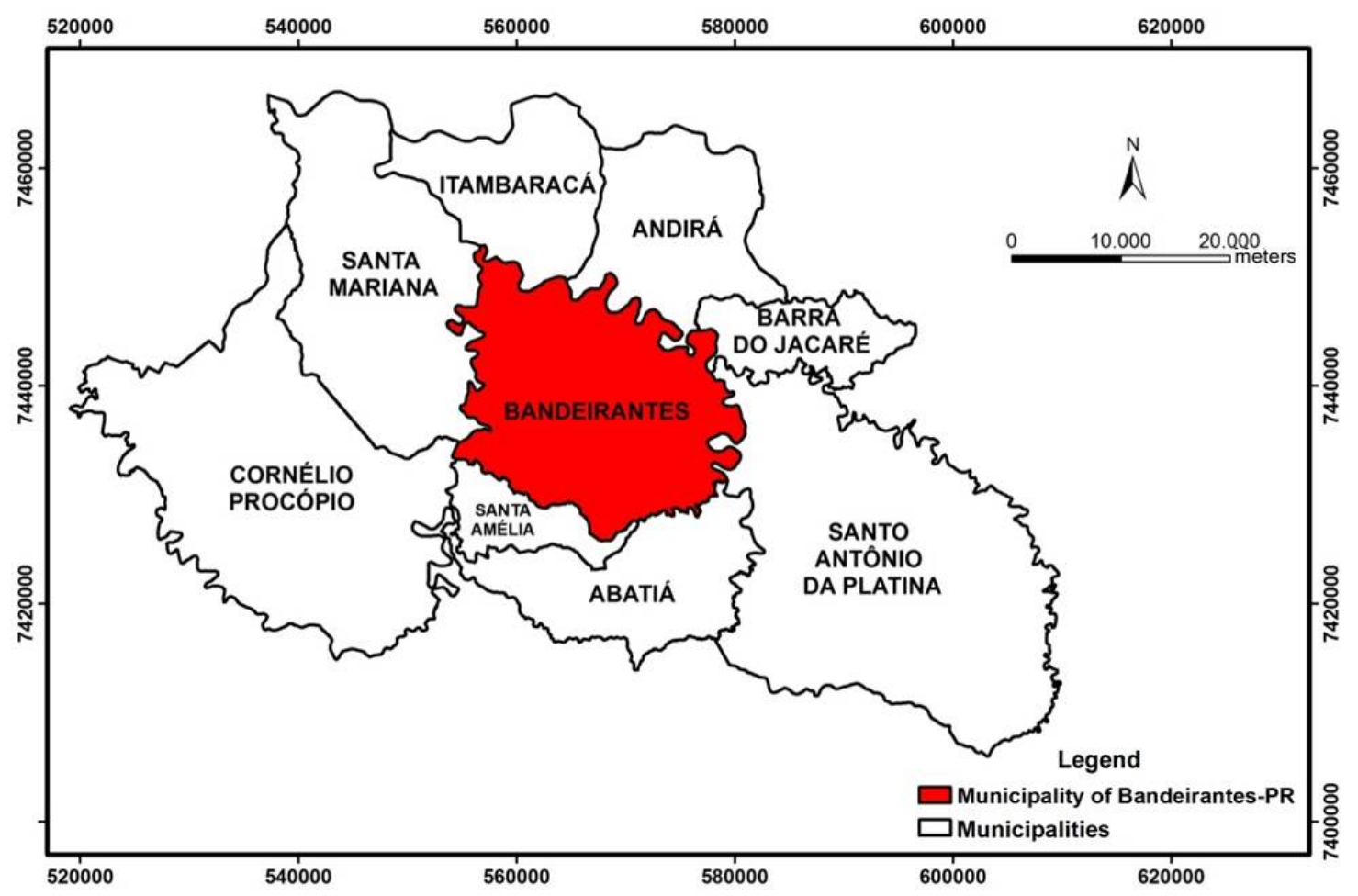

The cartographic base, consisting of charts drawn up by the Brazilian Institute of Geography and Statistics (IBGE) at 1:50,000 scale, using UTM projection, the Imbituba, SC vertical datum, and the regional geodetic system SAD 69. Sheets MI 2760-1, MI 2760-2, MI 2760-3 and MI 2760-4 were input into the system using a table scanner, and then digitized and georeferenced in ArcGIS, version 9.3.1 (ESRI, 2008). The datums were transformed to SIRGAS 2000 projected coordinate system using the Data Management Tools. The contour lines, which are at $20 \mathrm{~m}$ vertical intervals, were digitized (Figure 2), yielding a DTM in a thematic information plan. Triangulated Irregular Networks (TIN) was used to generate this model, in which elevations are produced by using the sample data points to generate a triangular network of vertices from which triangular facets are rendered. 
Figure 2. Map of the contour lines of the Bandeirantes-PR municipality.

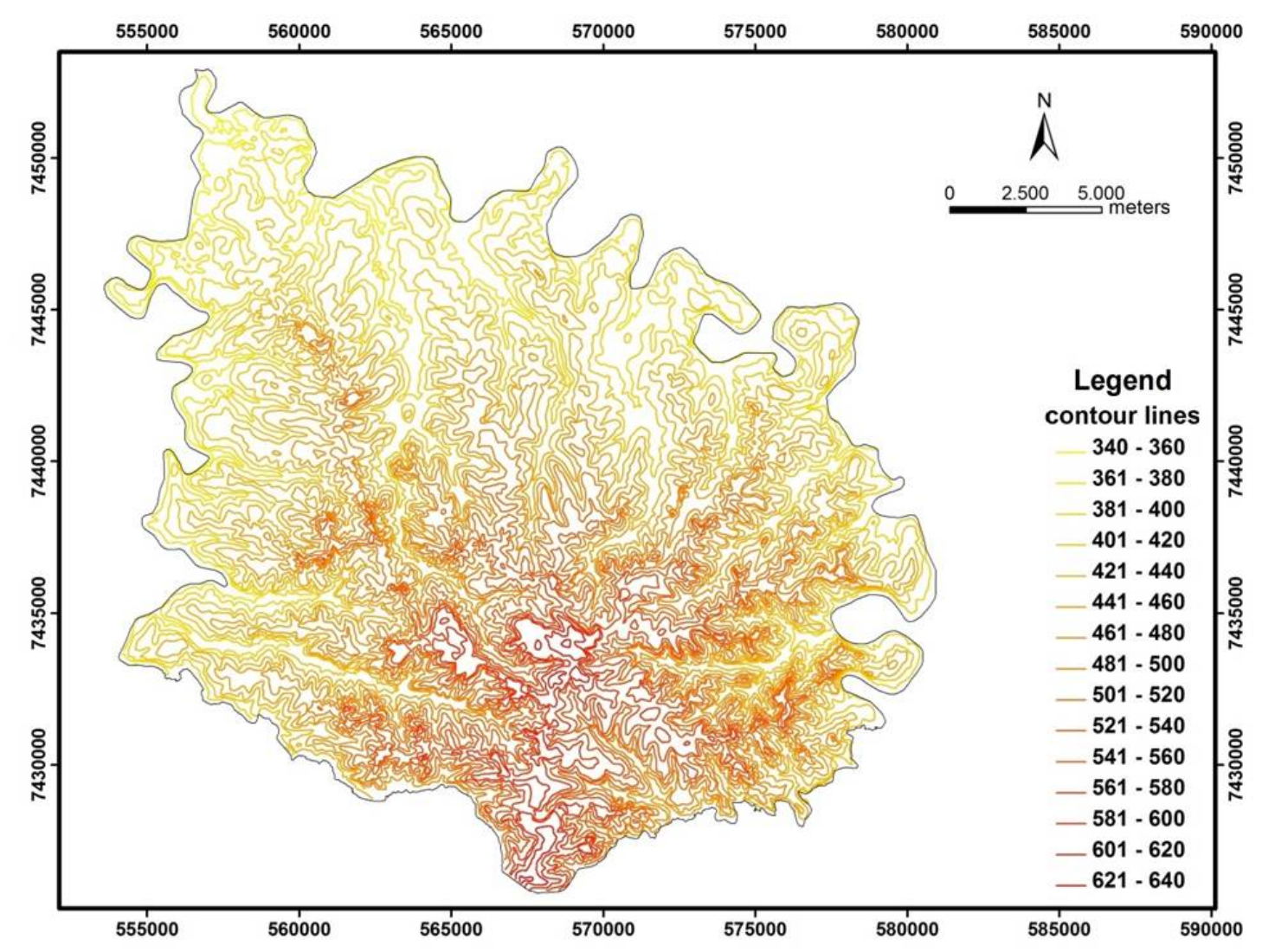

In terms of orbital sensor images, it was decided to acquire and process the ASTER GDEM and SRTM images covering the study area. In order to obtain the slope data, it was necessary to transform the coordinate reference system and datum from WGS 84 to SIRGAS 2000 using the Data Management Tools. This was followed by the extraction of the area corresponding area to the Bandeirantes-PR municipality using the mask extraction process in the Spatial Analyst extension.

The TIN of the images from orbital sensors were generated by extracting contour lines using the 3D Analyst extension, in accordance with the spatial resolution of each image, namely 90 x $90 \mathrm{~m}$ (SRTM) and $30 \times 30 \mathrm{~m}$ (ASTER GDEM). Slope was added under the Symbology tab of the Layer properties for classification of the TIN of the study area. It was not necessary to generate DTM extraction curves, since the SRTM and ASTER GDEM correspond to a continuous mathematical representation of the terrain, with the variation in elevation of the area defined by a cartographic plan in a set of evenly distributed coordinates.

In terms of the application of kriging, after digitizing the chart, a total 992 points of elevation were sampled by the vectorization process in ArcGIS. The points of elevation were randomly sampled from the contours, and from points of maximum and minimum elevation (Figure 3). Analysis of the elevation data was performed by the kriging geostatistical technique. Kriging was done to check and measure the degree of spatial dependence from the adjustment of theoretical functions to the experimental variogram model, based on the assumption of stationarity, and according to the equation expressed by Landim (1998). 
Figure 3. Map of the randomly selected sampling points of elevation for kriging.

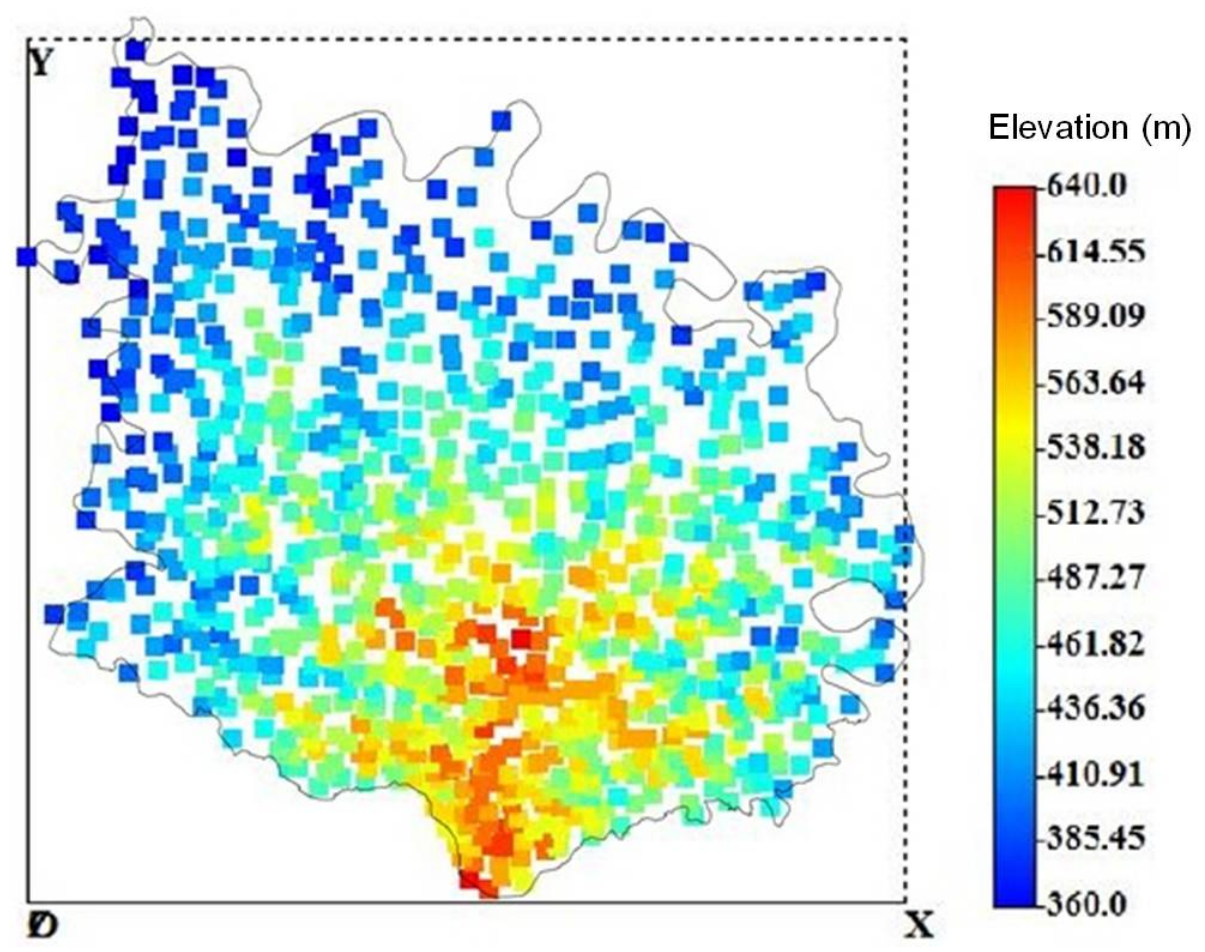

$$
\left.\gamma(h)=\frac{1}{2 N(h)} \sum_{i=1}^{N(h)} \llbracket\left[Z(\square] x_{i}\right)-Z\left(x_{i}+h\right)\right]^{2},(1)
$$

where $N(h)$ is the number of experimental pairs of observations $\mathrm{Z}\left(\mathrm{x}_{\mathrm{i}}\right), \mathrm{Z}\left(\mathrm{x}_{\mathrm{i}}+\mathrm{h}\right)$, separated by a vector $\mathrm{h}$.

In the adjustment of the theoretical model to the experimental variogram, the coefficients nugget $\left(\mathrm{C}_{0}\right)$, sill $\left(\mathrm{C}_{0}+\mathrm{C}\right)$ and range $\left(\mathrm{A}_{0}\right)$ were determined. To check the spatial dependence, we used the spatial dependence index proposed by Zimback (2001). We used universal kriging to interpolate the values of elevation in areas not sampled, and to draw up contour maps due to the variable of study having presented a regional trend or drift in which we applied a variogram of residues and a model to describe the shape of the trend, i.e., an ordinary kriging of the residues after the removal of the trend by linear regression.

Using the 3D Analyst extension, it was then possible to obtain thematic slope maps of the municipality of Bandeirantes-PR using as input the
MNT scanned contours, SRTM, ASTER GDEM, and kriging.

To build the slope maps, we established the slope classes prevailing in the area of interest based on the operating slope/declivity (d) of the agricultural harvesters corresponding to the ranges of $0<\mathrm{d} \leq$ $12 \%, 12<\mathrm{d} \leq 21 \%$ and $\mathrm{d}>21 \%$. These limit values were defined based on the State law No. 11241 of 19 September 2002 of the State of São Paulo (SÃO PAULO, 2014), which regulates the gradual elimination of sugarcane straw burning and provides related measures. For the purposes of this law, areas in plantations over 150 ha are considered to be mechanized, and areas with slopes equal to or less than $12 \%$ are suitable for full mechanization. Areas with slopes $>12 \%$ and $\leq 21 \%$ are suitable with restrictions, given that the manuals of current harvesters guarantee machining in areas up to these slope values, but with restrictions on the soil conditions and the center of gravity of the machine (RIPOLI; RIPOLI, 2004). Finally, the areas with slopes above $21 \%$ are classified as unsuitable in their entirety. 


\section{Results and Discussion}

Figure 4 shows the results of statistical analysis of the elevation data sampled during the vectorization of the contour lines. The coefficient of variation $(\mathrm{CV})$ of the data collected during vectorization of contour lines is $13 \%$. According to Pimentel Gomes (1987), data with CV from 10 to $20 \%$ can be considered as average variability. This average variability can be attributed to the large number of data samples (992 points), in addition to the intrinsic characteristics of the topography of the region. The data did not present a normal distribution, as indicated by the disparity between the values of the mean, median and mode (i.e., $481.5 \mathrm{~m}, 480 \mathrm{~m}$ and $460 \mathrm{~m}$, respectively), which show positive asymmetry with the mean greater than the median and mode, and confirmed by the Shapiro-Wilks normality test at $5 \%$ probability $\left(\mathrm{w}=0.97^{\mathrm{ns}}\right)$. On the positive asymmetry, there is a tendency that the distribution of the variable focus around the lower values (LIBARDI et al., 1996; OLIVEIRA et al., 2008) observed in the sampling map of the variable under study in Figure 3, where these are high values of elevation corresponding to a localized and relatively rare situation given the total area. According to Isaaks and Srivastava (1989), more important than the normality of the data, is the presence or absence of a so-called proportional effect, in which the average and variability of the data are listed, as in this study. However, in the case of data obtained in nature, adjusting a theoretical distribution is only approximate (WARRICK; NIELSEN, 1980). Once it is proven that there are attributes without normal distributions of their data, the importance of geostatistics in addition to classical statistics in interpreting these attributes with more clarity and certainty becomes clear, as described by Jakob (1999).

Figure 4. Variogram and table of properties determined in the geostatistical analysis, and descriptive statistics of the elevations obtained from the topographic map.

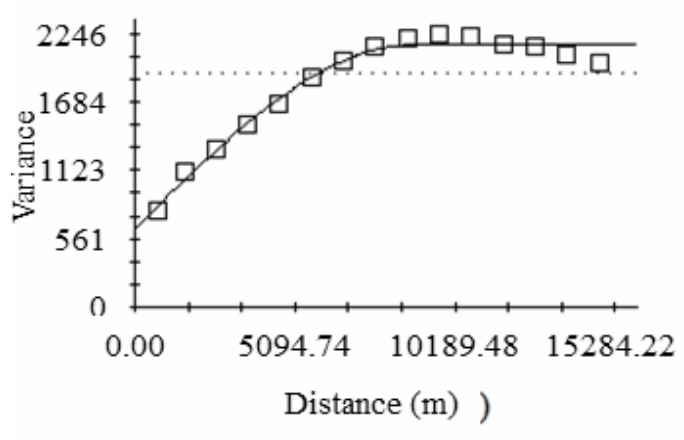

The variogram and the table with the adjusted parameters and models for the elevation variable are shown in Figure 4. The spherical model presented was the model that best fit the experimental variogram with a range of $8820 \mathrm{~m}$. Several studies indicate this model is the most appropriate to describe the variograms behavior with respect to soil attributes and different gradients of slope and landforms (TRANGMAR et al., 1985; SANCHEZ et al., 2005; LIMA et al., 2012.).

\begin{tabular}{ll}
\hline Geoestatistica & Estatistica descritiva \\
\hline Modelo esférico & Minimo $=360 \mathrm{~m}$ \\
$\mathrm{C}_{0}=641$ & Máximo $=640 \mathrm{~m}$ \\
$\mathrm{C}_{0}+\mathrm{C}=2150$ & Média $=481.5 \mathrm{~m}$ \\
$\mathrm{~A}_{0}=8820 \mathrm{~m}$ & Mediana $=480 \mathrm{~m}$ \\
$\mathrm{R}^{2}=0.982$ & Desvio padrão $=63.47 \mathrm{~m}$ \\
$\mathrm{IDE}=70 \%$ & $\mathrm{CV}=13 \%$ \\
\hline
\end{tabular}

The analysis of the fraction $\left[\mathrm{C}_{0} /\left(\mathrm{C}_{0}+\mathrm{C}\right)\right]$ was expressed in accordance with the classification proposed by Zimback (2001), whose variable is within the limits of the spatial dependence index of moderate to strong ( $25 \%>$ IDE $<75 \%)$. In practice, this means that the average of the elevation is not random in the area, and that it has a spatial dependence structure, and that these variogram parameters allow the estimation by ordinary kriging 
of values in unmeasured locations. This study indicates weak spatial dependence due to the high variability of the data in the area (VALERIANO, 2003), although high spatial dependence has also been detected (BARBOSA et al., 2012).

The numerical terrain models of the different methods employed are shown in Figure 5. From the construction of the DTMs, it was possible to generate slope maps, and these were in turn used as parameters in determining the agricultural mechanization practices for harvesters. Therefore, the more accurate the DTM, that is the better the sampling of ground elevation points and their interpolation, the more representative is the slope map.

Figure 5. Digital terrain model using the TIN method (A), ASTER GDEM (B), SRTM (C) and kriging (D).

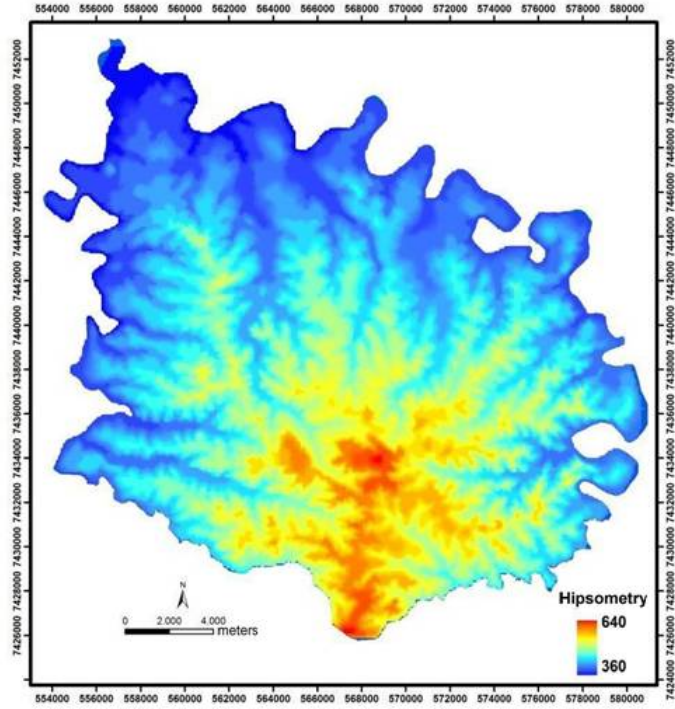

A.

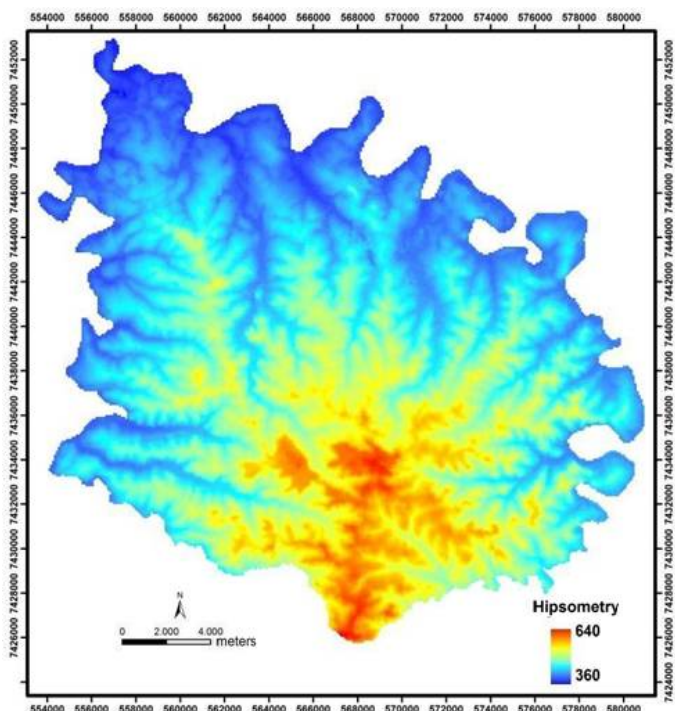

C.

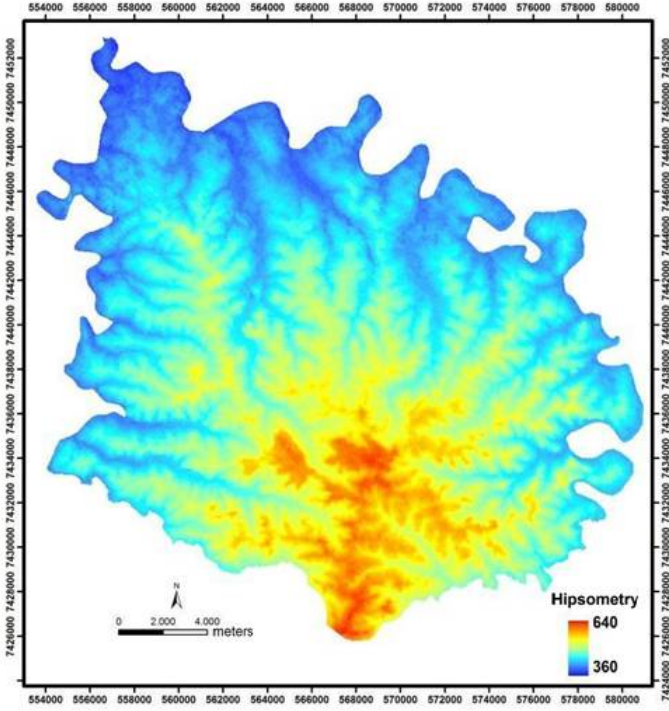

B.

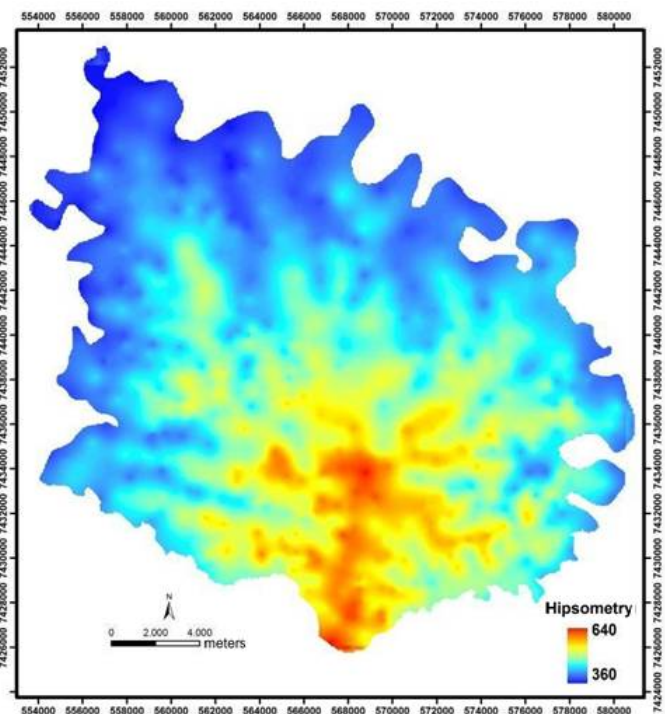

D. 
Although the DTM maps obtained have similar distribution of elevation, the slope maps show distinct differences in the terrain classes of the different methods of obtaining the DTM (Figure 6). The slope maps acquired through the digitization of contour lines and ASTER GDEM images showed greater representativeness of the variation, since the mapping of the slope requires high spatial resolution (VALERIANO, 2003). This confirms the results obtained, since the interpolations have been performed on data with spatial resolution in the range of $20 \mathrm{~m}$ and $30 \mathrm{~m}$, respectively. The contours digitization method gave the most realistic DTM, but because the cartographic base is old, dating back to 1973, it may have suffered some influences from land use and occupation. In addition, manual measurement of slope on maps with contours is tiring work, and thus subject to error (VALERIANO, 2003).

Figure 6. Slope map obtained by the digitizing method (A), ASTER GDEM (B), SRTM (C) and kriging (D).

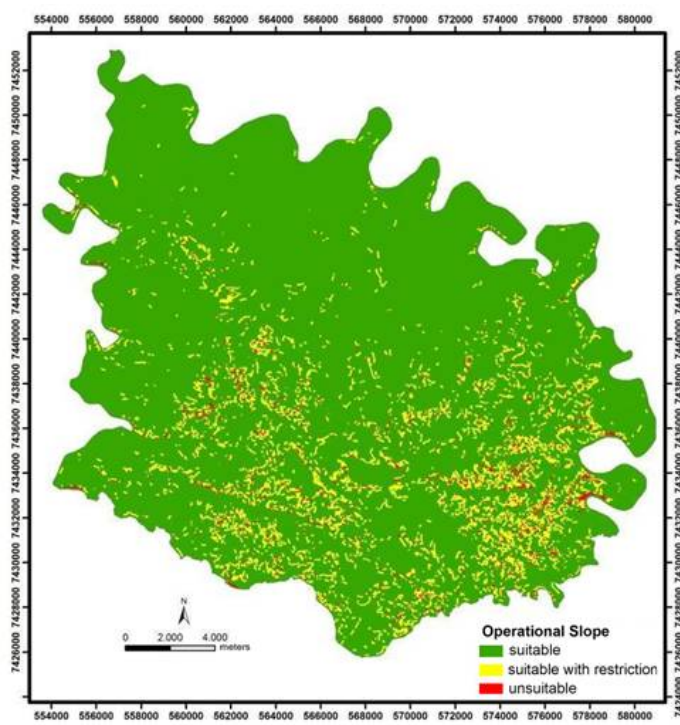

A.

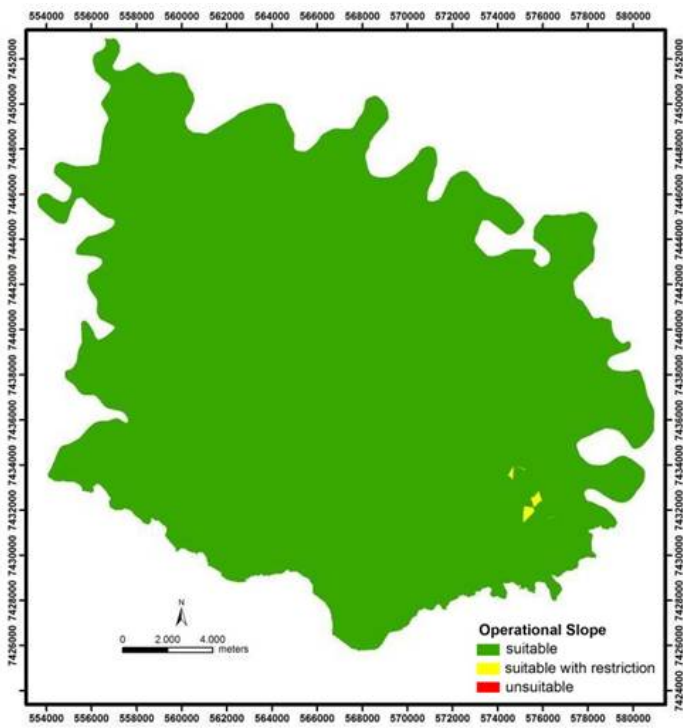

C.

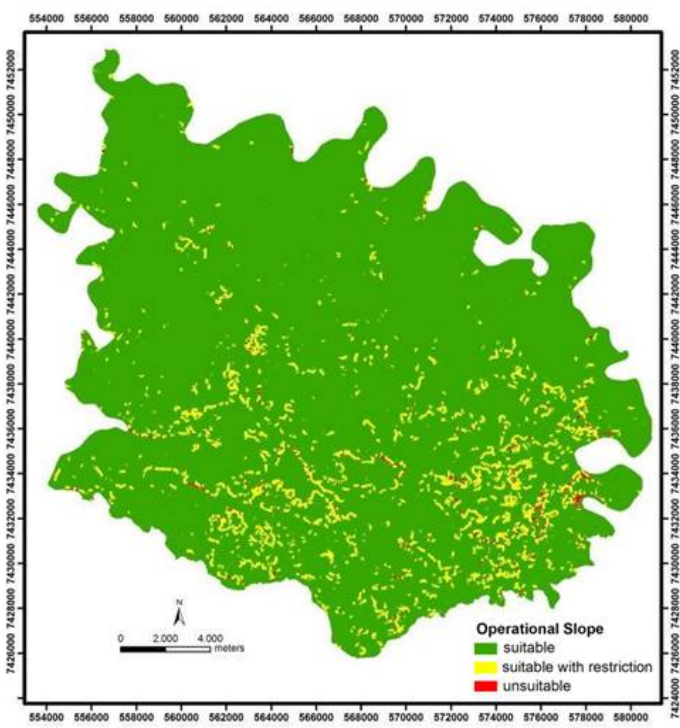

B.

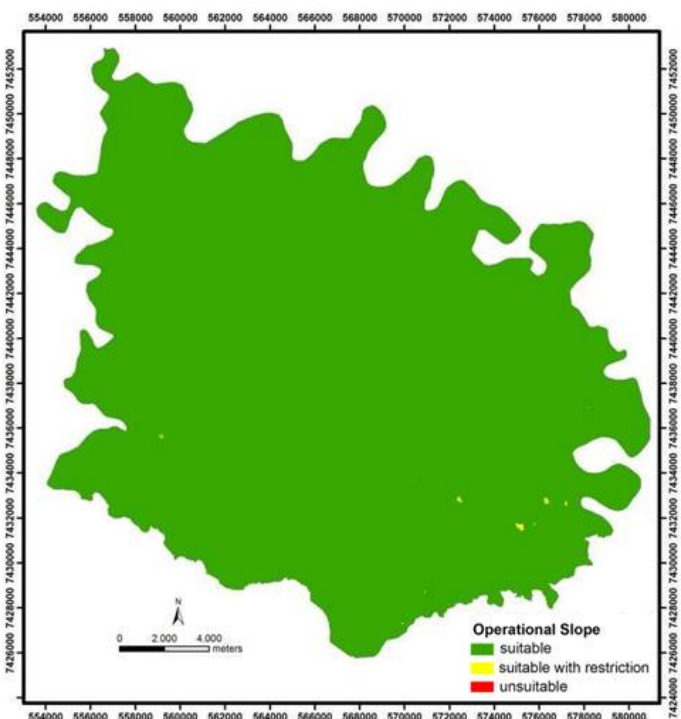

D. 
The ASTER GDEM images showed similar features when compared to the contour digitization method. It should be noted that the acquisition and processing of this information is easier and faster, as well as being update, since the public release of the data in 2011.

The results of the processing of SRTM images and from the kriging interpolation were similar, regardless of the use of SRTM data, or that the number of randomly chosen points sampled for kriging was 992. The similarity between the two methods is a function of the number of sampling points. The kriging map could be similar to the digitized contour map, if there had been a greater number of sample points, since the spatial kriging estimate improves with the more points or information. However, besides being a laborious method, most software and GIS have limitations on the amount of data for geostatistical processing. Still, in relation to the data produced on the SRTM mission, 1 arc or $30 \mathrm{~m}$ resolution data is available for the USA, whereas 3 arc or $90 \mathrm{~m}$ resolution data in the Lat/Long coordinate system and with the WGS84 Datum are available for South America (SILVA et al., 2013).
The slope maps revealed large differences in relation to the area of the terrain classified into the different slope classes, when comparing resolutions of $20 \mathrm{~m}$ (contour), $30 \mathrm{~m}$ (ASTER) and $90 \mathrm{~m}$ (SRTM). As a result, the slope maps derived from high resolution DTMs presented suitable areas, suitable with restrictions, and unsuitable areas that match scenarios encountered in the field. Thus, the slope mapping requires high spatial resolution for adequate representation of the variation, especially in the range of high elevation values.

In Table 1, the disparities between the areas of the different methods classified with respect to the operational slope classes are apparent. The suitable class $(0<\mathrm{d} \leq 12 \%)$ of the SRTM showed the greatest area $(44,442.45 \mathrm{ha})$, corresponding to $99.9 \%$ of the entire area of the municipality. The suitable with restrictions class $(12 \%<\mathrm{d} \leq 21 \%)$ had significant values only in methods with high resolution (digitization of contours and ASTER GDEM). The unsuitable class (> $21 \%$ ), including the areas of the scanned images of contours (649.89 ha) and the ASTER GDEM (201.7 ha), show the importance of high-resolution images in this type of study.

Table 1. Areas classified in terms of the operational slope for agricultural harvesters by different DTM processing methods.

\begin{tabular}{lccc}
\hline \multirow{2}{*}{ DTM Method } & \multicolumn{3}{c}{ Classification } \\
\cline { 2 - 4 } Contour digitization & Suitable & Suitable with restrictions & Unsuitable \\
& 39708.88 ha & 4129.83 ha & \multirow{2}{*}{649.89 ha $(1.46 \%)$} \\
\hline \multirow{2}{*}{ ASTER GDEM } & $(89.24 \%)$ & 2909.85 & $201.7(0.46 \%)$ \\
& 41377.05 & $(6.54 \%)$ & 0.00 \\
\multirow{2}{*}{ SRTM } & $(93.00 \%)$ & 46.15 & $0.00 \%$ \\
\hline \multirow{2}{*}{ Kriging } & 44442.45 & $(0.10 \%)$ & 2.78 \\
& $(99.90 \%)$ & 19.35 & $(0.01 \%)$ \\
\hline
\end{tabular}

In areas with appropriate slope for mechanical harvesting, lying in the range of 0 to $12 \%$ slope, the methods of sampling did not present large differences in area. In the areas suitable with restrictions and unsuitable (slopes from $12 \%$ to $21 \%$, and above $21 \%$, respectively), there was a greater difference in quantifying the areas between the four methods of obtaining the DTMs. This is 
due to the resolution of the images and the density of the sampling points, which produces a smoothing effect of the terrain in the lower resolution cases of SRTM and kriging.

The methods used for the construction of DTMs allowed operating slope maps for agricultural harvesters to be obtained that were compatible with their respective spatial resolutions. For these purposes, it is not advisable to calculate slopes with a resolution lower than $20-30 \mathrm{~m}$.

\section{Conclusions}

The construction of DTMs for the purpose of determining the area with suitable slopes for operating agricultural machinery enables a view of the landscape found in the field with precision, speed and quality of information.

The four methods of acquiring the DTM allowed operating slope maps for agricultural harvesters to be obtained of the Bandeirantes municipality.

Regardless of the method used to obtain the operating slope maps, the municipality has a large area (>89\%) suitable for mechanized harvesting.

\section{References}

ADVANCED SPACEBORNE THERMAL EMISSION AND REFLECTION RADIOMETER - ASTER. ASTER GDEM. Global Digital Elevation Map Announcement. California: Nasa, 2012. Available at: <http://gdem. ersdac.jspacesystems.or.jp/>. Accessed at: 10 feb. 2015.

BARBOSA, A. P.; SILVA, A. F. da; ZIMBACK, C. R. L. Modelo numérico do terreno obtido por diferentes métodos em cartas planialtimétricas. Revista Brasileira Engenharia Agrícola e Ambiental, Campina Grande, v. 16, n. 6, p. 655-660, 2012.

CAMPOS, M. C. C.; MARQUES JÚNIOR, J.; PEREIRA, G. T.; SOUZA, Z. M.; MONTANARI, R. Planejamento agrícola e implantação de sistema de cultivo de cana-deaçúcar com auxílio de técnicas geoestatísticas. Revista Brasileira de Engenharia Agrícola e Ambiental, Campina Grande, v. 13, n. 3, p. 297-304, 2009.
CHAGAS, C. S.; FERNANDES FILHO, E. I.; ROCHA, M. F.; CARVALHO JÚNIOR, W.; SOUZA NETO, N. C. Avaliação de modelos digitais de elevação para aplicação em um mapeamento digital de solos. Revista Brasileira de Engenharia Agrícola e Ambiental, Campina Grande, v. 14, n. 2, p. 218-226, 2010.

DEUTSCH, C. V.; JOURNEL, A. G. Geostatistical Software Library and user's guide. Nova York: Oxford University Press, 1998. 339 p.

EMPRESA BRASILEIRA DE PESQUISA AGROPECUÁRIA - EMBRAPA. Centro Nacional de Pesquisa de Solos. Sistema Brasileiro de Classificação de Solos. 3. ed. Brasília: EMBRAPA, 2013. 353 p.

ENVIRONMENTAL SYSTEMS RESEARCH INSTITUTE - ESRI. Inc. ArcGIS Professional GIS for Desktop. Version 9.3.1. Software. Louisiana: ESRI, 2008.

INSTITUTO BRASILEIRO DE GEOGRAFIA E ESTATÍSTICA - IBGE. Bandeirantes, Rio de Janeiro: IBGE, 2012. Available at: <http://cod.ibge.gov.br/1IJU>. Accessed at: 5 feb. 2015.

ISAAKS, H. E.; SRIVASTAVA, R. M. An introduction to applied geostatistics. New York: Oxford University Press, 1989. $561 \mathrm{p}$.

JAKOB, A. A. E. Estudo da correlação entre mapas de variabilidade de propriedades do solo e mapas de produtividade para fins de agricultura de precisão. 1999. Dissertação (Mestrado em Engenharia Agrícola) Faculdade de Engenharia Agrícola, FEAGRI, Campinas.

JET PROPULSION LABORATORY - JPL. Shuttle Radar Topography Mission (SRTM). San Jose: NASA, 2012. Available at: <http://www2.jpl.nasa.gov/srtm/ dataprod.htm>. Accessed at: 10 feb. 2015.

KARKEE, M.; STEWARD, B. L.; AZIZ, S. A. Improving quality of public domain digital elevation models through data fusion. Biosystems Engineering, Londres, v. 101, n. 3, p. 293-305, 2008.

LANDIM, P. M. B. Análise estatística de dados geológicos. São Paulo: UNESP, 1998. 226 p.

LIBARDI, P. L.; MANFRON, P. A.; MORAES, S. O.; TUON, R. L. Variabilidade da umidade gravimétrica de um solo hidromórfico. Revista Brasileira de Ciências do Solo, Viçosa, MG, v. 20, n. 1, p. 112-120, 1996.

LIMA, J. S. S.; OLIVEIRA, R. B.; SILVA, S. A. Spatial variability of particle size fractions of an Oxisol cultivated with conilon coffee. Revista Ceres, Viçosa, MG, v. 59, n. 6, p. 867-872, 2012.

MAACK, R. Geografia física do Estado do Paraná. Curitiba: BADEP: UFPR: IBPT, 1968. 526 p. 
OLIVEIRA, R. B.; LIMA, J. S. S.; XAVIER, A. C.; PASSOS, R. R.; SILVA, S. A.; SILVA, A. F. Comparação entre métodos de amostragem do solo para recomendação de calagem e adubação do cafeeiro conilon. Engenharia Agrícola, Jaboticabal, v. 28, n. 1, p. 176-186, 2008.

OLIVEIRA, R. B.; XAVIER, A. C.; QUARTO JÚNIOR, P.; SILVA, A. F.; LIMA, J. S. S. Mapeamento das áreas aptas para tráfego de tratores agrícolas no município de Alegre-ES. In: ENCONTRO LATINO AMERICANO DE INICIAÇÃO CIENTÍFICA E ENCONTRO LATINO AMERICANO DE PÓS-GRADUAÇÃO, 9; 5., 2006, São José dos Campos. Anais... São José dos Campos: UNIVAP, 2006. p. 596-598.

ORTEGA, A. C.; JeSUS, C. M.; MOURO, M. C. Mecanização e emprego na cafeicultura do cerrado mineiro. Revista ABET, João Pessoa, v. 3, n. 2, p. 58-82, 2009.

PIMENTEL GOMES, F. Curso de estatística experimental. 12. ed. São Paulo: Nobel, 1987. 467 p.

REIS, L. C.; REIS, T. E. S.; ABI SAAB, O. J. G. Diagnóstico das áreas de preservação permanente das microbacias hidrográficas do município de Bandeirantes - Paraná. Semina: Ciências Agrárias, Londrina, v. 30, n. 3, p. 527-536, 2009.

RIPOLI, T. C. C.; RIPOLI, M. L. C. Biomassa de canade-açúcar: colheita, energia e ambiente. 2. ed. Piracicaba: [s.n], 2004. 302 p.

SANCHEZ, R. B.; MARQUES JÚNIOR, J.; PEREIRA, G. T.; SOUZA, Z. M. Variabilidade espacial de propriedades de latossolo e da produção de café em diferentes superfícies geomórficas. Revista Brasileira de Engenharia Agrícola e Ambiental, Campinas, v. 9, n. 4, p. 489-49, 2005.

SÃO PAULO. Lei Estadual $N^{o}$ 11. 241, de 19 de setembro de 2002. Dispõe sobre a eliminação gradativa da queima da palha da cana-de-açúcar e dá providências correlatas. 2014. Disponível em: <http://www.al.sp. gov. br/repositorio/legislacao/lei/2002/lei-11241-19.09.2002. html>. Acesso em: 06 set. 2016.
SILVA, I. C. O.; ALVES, R. E.; RODRIGUES, T. L. Análise de variáveis morfométricas extraídas a partir de imagem SRTM para elaboração de mapa pedológico. Geoambiente, Jataí, v. 20, n. 20, p. 1-15, 2013.

SMITH, M. P.; ZHU, A. X.; BURT, J. E.; STILES, C. The effects of DEM resolution and neighborhood size on digital soil survey. Geoderma, Amsterdam, v. 155, n. 1-2, p. 55-66, 2006.

SOUSA JÚNIOR, J. G. A.; DEMATTÊ, J. A. M. Modelo digital de elevação na caracterização de solos desenvolvidos de basalto e material arenítico. Revista Brasileira de Ciência do Solo, Viçosa, MG, v. 32, n. 1, p. 449-456, 2008.

TRANGMAR, B. B.; YOST, R. S.; UEHARA, G. Application of geostatistics to spatial studies of soil properties. Advances in Agronomy, San Diego, v. 36, n. 1, p. 45-93, 1985.

VALERIANO, M. M. Mapeamento da declividade em microbacias com Sistemas de Informação Geográfica. Revista Brasileira de Engenharia Agrícola e Ambiental, Campina Grande, v. 7, n. 2, p. 303-310, 2003.

VIVIANI, E.; MANZATO, G. G. Geração de modelos digitais de superfície por meio de plataformas computacionais com estrutura vetorial e raster. Ciência e Engenharia, Uberlância, v. 14, n. 2, p. 27-34, 2005.

WARRICK, A. W.; NIELSEN, D. R. Spatial variability of soil physical properties in the field. In: HILLEL, D. (Ed.). Applications of soil physics. New York: Academic Press, 1980. p. 319-344.

ZIMBACK, C. R. L. Análise espacial de atributos químicos de solos para fins de mapeamento da fertilidade do solo. 2001. Tese (Livre-Docência em Agronomia) Faculdades de Ciências Agrárias, Universidade Estadual Paulista. Botucatu. 
